\title{
DIRECT DEMOCRACY IN SOUTHERN AND EAST AFRICA \\ Referendums and Initiatives
}

\author{
Norbert Kersting \\ Prof Norbert Kersting holds the Willy Brandt Chair on Transformation \\ and Regional Integration (DAAD) in the Department of Political Science, \\ Stellenbosch University \\ e-mail: kersting@sun.ac.za
}

\begin{abstract}
There seems to be a worldwide trend towards direct democracy instruments such as referendums and initiatives. The African Union Charter (2007) and the New Partnership for Africa's Development (Nepad) strategy papers (2003) recommend these instruments. Is direct democracy the panacea for the problem of strong personalisation of African party politics? If electoral democracy is the problem, is direct democracy the solution? The article describes the legal framework and the implementation in countries in Southern and East Africa. Referendums, which are solely implemented at the national level, were often used to support regime change in the 1960s (independence) and in the 1990s (multiparty systems) and to strengthen and finalise conflict resolution. Plebiscites, characterised by strong executive governmental campaigning and party dominance predominate and citizen initiatives are not common. The implementation of citizen initiatives at both national and local level could be an additional way of strengthening accountability.
\end{abstract}

\section{INTRODUCTION}

In the old advanced democracies direct democracy instruments such as referendums are often regarded as sophisticated, but because they give power to the people they are also regarded by politicians with a great deal of scepticism.

Some countries, for instance the United States, use them predominantly at the local level (Kersting 2007). At the national level they are extensively used in Italy (abrogative and constitutional referendums) and in the motherland of direct democracy, Switzerland. But in most countries referendums are restricted to the (supra-) national level (see, eg, Germany). 
The direct inclusion of citizens may have a strong influence on the development of policies and institutions. In Europe, the Eastern European states held successful referendums supporting membership of the European Union (EU), a positive attitude which vanished in some countries during the debate over the EU's constitution. After a long process of deliberation involving political elites in the Constitutional Assembly and an agreement by heads of state in the European council, the citizens of most of the countries were asked to approve the new draft of the constitution. In France and the Netherlands the people failed to do so and the process of implementation of the new legislative framework was halted.

Other continents, however, have had more positive experiences. In some Latin American countries, Uruguay, Ecuador, and Venezuela, for instance, direct democracy seems to be enjoying a new honeymoon (Altmann 2003).

With few exceptions, among them Uganda, Malawi, and Kenya, there has been almost no research into African referendums. This paper, which is intended to be a starting point for such comparative research, shows the existing legal framework without providing an in-depth legalistic perspective. What kind of direct democracy instruments have already been implemented? Do referendums work in the neo-patrimonial systems that often predominate in Africa? Do they make sense in de facto one-party democracies? Is there a need for more direct democracy in the African context, as requested in the African Union Charter (2007) and the New Partnership for Africa's Development (Nepad) strategy paper (2003)? All these questions must be analysed.

Direct-democratic procedures can be considered in terms of two criteria. The first is the quality of direct-democratic processes that are brought to the fore, the second is to what extent these processes qualify for a public discourse. Are propaganda, public manipulation, and demagogy central characteristics of referendums or will referendums lead to a better understanding of society and responsiveness (Arnstein 1969; Hatchard, Ndulo \& Slinn 2004, p 57). Most investigations of direct democracy have been based only on empirical nonreviewed hypotheses. Analysis has shown that the historical arguments on the subject do not stand up empirically because they have relied on traditional prejudices against direct democracy.

This paper is merely a starting point for a deeper analysis of direct democracy in Africa. More information about the legal framework and the implementation of referendums is still to be gathered (Marques \& Smith 1984; Butler \& Ranney 2000; IDEA 2008) and once it has been, typologies of referendums will be developed. The analysis of the effects of referendums will include their function and their influence on the stability and legitimacy of different African political systems (Dahl 1971).The analysis of direct democracy here is restricted to Southern and East Africa. Avoiding West Africa and the 'semi-presidential' francophone 
political systems leads to a more homogeneous selection of cases (Bratton, Mattes \& Gyimah-Boadi 2005, pp 61ff). The influence of French colonisation on the implementation of 'presidential referendums' can be seen as an additional disturbance factor. Because of the low profile of referendums in the British system, where direct democracy has only recently enjoyed a honeymoon, anglophone African countries are not expected to be frontrunners, a colonial factor that will be analysed in a later article.

I describe only briefly the situation in most Southern and East African countries, apart from Zimbabwe and Kenya, which may be considered typical cases of failed referendums.

The analysis begins with definitions of the range of instruments of direct democracy in order to correct misleading misconceptions about these instruments. In the next section the main arguments for and against direct democracy will be discussed. This will be followed by examples of the implementation of direct democracy instruments in Southern and East Africa and an attempt to analyse the reasons for the existence of such instruments in Africa. Were they implemented for nation-building purposes, or to strengthen incumbent elites, or to reinvigorate inclusive governance? Finally, the pro- and contra-arguments will be analysed in the African context and the first conclusion will be drawn.

\section{DEFINITION OF DIRECT DEMOCRACY}

Modern democracies, and especially political systems in Southern and East Africa, are frequently regarded as electoral democracies because their citizens are able to vote for political parties. However, these political parties often do not offer options and the elections are 'choiceless'. Nevertheless, elections are the only instruments for broad mass participation (Kersting 2007, p 141; Lindberg 2004). Civil society engagement, demonstrations, and so on, are often instruments for the political participation of a small elite.

Direct democracy, which is direct engagement in favour of or against certain political issues (Schiller 2002), is issue-oriented, not person-oriented (IDEA 2004). Direct election of the mayor or the president and forms of recall are considered to be representative democracy. Regular direct elections in representative democracies are not included in the concept of direct democracy used in this paper. Recalls as proactive instruments initiated by citizens are included, but are analysed separately (IDEA 2004).

In our definition direct democracy refers to different forms of political participation in which people vote in favour of or against certain constitutional, legislative, or policy issues. This means it focuses on issues, on a vote, and on majorities, or, as Schmitter \& Trechsel (2004) define it, it is part of 'numeric 
democracy'. The term 'referendum' is frequently used, as it is in this article, in place of 'direct democracy', although in some countries a referendum, as we will see, is only one particular form of direct democracy.

Direct democracy instruments share at least three main characteristics, but they differ in terms of initiation, thresholds, and quorums, topical regulations and their binding character. Because of the many different institutional settings the evaluation of direct democracy is complex (Schiller \& Mittendorf 2002; Kaufmann \& Waters 2004).

\section{Initiation}

A direct democracy instrument can be proactive and initiated from below (citizen initiative) or 'from above' (by the legislative or the executive bodies). In a decisionmaking process it can be seen as the final decision.

The opportunity for citizens to initiate a decision-making process which, after passing through Parliament and the executive, is finally decided by themselves (by the people for the people) is regarded as an advancement in democracies (Rousseau). This right of initiation results in a higher responsiveness within the representative political system, with politicians formulating policies in such a way that they pre-empt the necessity for turning to the people for approval.

The Ugandan Constitution (1995) provides for a bottom-up citizen's initiative. Article 255 of the Constitution states that:

... parliament shall by law make provision: (a) for the citizens' right to demand the holding by the Electoral Commission of a referendum, whether national or in any particular part of Uganda, on any issue ...

To avoid a plethora of referendums this process is highly formalised and restricted. In some cases an initiative begins with the collection, within a stated period, of a certain number of signatures; a form of petition. In general, the barriers to and costs of starting such a political process are relatively high.

The quorum for this submission (an initiative petition) depends on the size of the political entity involved. In Europe in bigger municipalities or provinces it is normally about three per cent of the population, while in small local authorities the percentage of signatories required may be as high as 15 per cent.

Article 74 of the Ugandan Constitution requires that a constitutional referendum be requested by half the members of Parliament and by a majority of the total number of members of each of at least half of all district councils. Or,

(c) if requested through a petition to the Electoral Commission by at least one-tenth of the registered voters from each of at least two- 
thirds of the constituencies for which representatives are required to be directly elected under article 78(1)(a) of this Constitution.

This can be regarded as a high threshold for a national referendum.

In some cases no 'supporting civil society' actor is necessary to initiate a direct democracy vote. Referendums may be abrogative, when applied to certain laws enacted by Parliament (Suksi 1993). In the case of such 'abrogative referendums', which are held to oppose a parliamentary decision, some countries impose a time limit on the collection of signatures for the petition.

Some countries, Ireland is one example, require that a mandatory referendum be held on international agreements and/or any constitutional amendments (Rourke, Hiskes \& Zirakzadeh 1992).

Referendums may also be initiated by Parliament. In such cases a twothirds majority of parliamentarians is generally required. The executive may also initiate a referendum and so, in some countries, may qualified minorities in Parliament.

In (semi-) presidential systems (such as those that govern most former French colonies and also those with 'Westminster presidentialism') 'presidential plebiscites' prevail. In some countries the president may propose a referendum without approval from Parliament. Such presidential referendums, or plebiscites, are often used strategically either as a reaction to public pressure or to resolve deep internal divisions over controversial policies (Suksi 1993).

\section{Quorum}

A petition carrying a minimum number of names is one barrier preventing the misuse of direct democracy, another is the use of quorums. So, in some countries, a relative, not an absolute, majority is sufficient to win a referendum. In general higher quorums are set for constitutional amendments (IDEA 2008).

There are two different types of quorum: a 'turnout quorum', which means that, for example, 50 per cent of the population must participate and if this quorum is not achieved, the referendum fails, no matter the result. This kind of quorum often leads to parties which oppose the goals of the referendum trying to demobilise voters by calling for a boycott.

Referendums today, however, largely take the route of the 'approval quorum', which mean that a certain number (in most cases 25 per cent) of registered voters must be in favour of the goal of the referendum and must constitute a majority.

There are advantages and disadvantages to setting quorums. On the one hand a quorum may diminish the success of the referendum, on the other, it precludes easy constitutional changes. 
Seychelles is the only country in East and Southern Africa to use a quorum, with electoral laws setting the percentage of the electorate required to endorse constitutional changes at 60 per cent.

In federal system such as that in Switzerland regional quorums require referendums to meet two goals - they must be won not only by a majority of the country's voters but by a majority of provinces.

\section{Topical regulation}

Direct democracy cannot be implemented in all areas of policy. Among those that are excluded in some countries are constitutional areas such as the Bill of Rights, budget policy, fiscal and financial policies, and decisions about personnel. In addition, in most countries (South Africa is one example) sensitive issues such as the death penalty cannot be decided by a referendum.

\section{Relevance and sustainability}

Direct democracy instruments may be consultative, their purpose being to advise the Parliament. They may also be binding, with the final decision made by citizens. They can have a 'suspensive' impact, which means a policy will not be implemented until the referendum is over, or a commitment impact, which means that another decision, for example one made by a Parliament, cannot overrule the decision made by the people.

\section{TYPES OF ‘REFERENDUMS’}

There are three main instruments of direct democracy (Suksi 1993), all of which are frequently referred to as referendums:

- Plebiscites are optional referendums initiated by political institutions, which allow the citizen a direct vote on a constitutional or legislative issue or a specific policy. Plebiscites are mostly facultative referendums initiated by the president or the Parliament (ruling or opposition party). Presidential plebiscites rarely require parliamentary approval.

- Obligatory referendums are mandatory and apply to particular circumstances and issues, set out either in the country's constitution or in other legislation. Amendments to the constitution, or disputes between the president and the legislature, may require a mandatory referendum. 
- Citizen initiatives are referendums in which the electorate votes on a measure proposed by the people. In such cases the proponents must collect enough signatures on a petition to support their argument. Citizen initiatives may focus on constitutional, legislative and policy matters. They may be proactive, which means they focus on an issue which is not on the agenda of the Parliament or government (a nondecision). They may be orientated towards a certain decision made by Parliament (abrogative referendum). In some cases the people are allowed to submit a proposal which must be dealt with in Parliament but which does not require the electorate to vote (agenda initiative).

In a citizen initiative the type of polling may be relevant to the success of the referendum. In some countries signatures may be collected on the streets, in others they may only be collected within the town hall and during office hours. Time limits for the collection of signatures differ - in some cases there is no time limit at all, in others, the period allowed may be very short.

Voter education is an important aspect of all referendums. In some countries voters are presented with printed information about the issues, in others, the initiators of a referendum are given financial support.

\section{DIRECT DEMOCRACY: PROS, CONS AND FUNCTIONS}

The discourse on direct democracy reveals deep divisions within the academic community. On one hand direct democracy is seen as the 'royal route', on the other, it is regarded as an instrument of mass manipulation and populism. The underlying assumption is that direct democracy is an instrument used in inclusive democracies - that referendums lend legitimacy, while representative democracy is elite driven and exclusive. Direct democracy is seen as a complementary instrument and not as an alternative to representative democracy.

Referendums, and especially 'bottom-up' citizen initiatives, have two different effects on the pre-legislative process. One, which is difficult to measure empirically, is their ability to diminish 'non-decisions' - political issues that are not discussed and are not on the agenda because elites fear a political discourse on the topic.

Since opposition parties and non-governmental organisations may use a citizen initiative as an additional instrument against a ruling party the mere fact that such a possibility exists may have its effects on politicians. The other effect can be measured more easily. After the initiation of a referendum or petition Parliament frequently takes over the idea and the process is stopped because Parliament has decided in favour of the initiators of the referendum. 
The most important argument focuses on the quality of the discourse. A referendum campaign is seen as a deliberative discourse of alternative issues, which leads to a higher rationality and to newly empowered citizen and politicians, factors that are missing when only Parliament debates an issue.

Arguments against direct democracy focus on the fact that it may lead to irrational decisions about complex issues and that it is possible to manipulate the masses to vote in a particular way (Rourke, Hiskes \& Zirakzadeh 1992). Indeed, empirical research shows that political parties use these instruments for their own ends and that opposition parties frequently try to use referendums when other methods of getting their way have failed.

In the African context, according to Bratton \& Van de Valle (1997, p 78), plebiscitary one-party systems, military oligarchies, settler oligarchies, competitive one-party systems and competitive multiparty systems predominate in neopatrimonial African regimes, with ruling parties and presidents using plebiscites to claim legitimacy.

At the national level referendums may have three main functions, which may interact. These are:

- National identity, nation building and state-building: In the process of state or nation-building referendums have a strong symbolic value, helping to legitimise new political institutions. In Africa, with its ethnically heterogeneous societies, referendums may be particularly important. Independence and the creation of new constitutions are often the result of agreements between elites. Referendums are seen as a way of democratising and legitimating these processes. Here they often have an acclamatory symbolic value, internally towards the citizen as well as outwardly towards the international community.

- Strengthening incumbent authorities: In some countries the playing field is not level and referendums appear to be predetermined. Incumbents employ controlled referendums in response to public pressure, using their power and control over the state to strengthen and extend their executive powers (Rourke, Hiskes \& Zirakzadeh 1992).

- Inclusive decision-making: In some countries the government, the executive, and the leading parties in Parliament are not strong enough to implement certain strategies. Deep internal societal divisions and controversial issues may be the motive for holding referendums. In others a stalemate requires an external judgement in the form of a referendum. In this situation the interests of ruling and opposition parties as well as other stakeholders come into play. 
The evaluation of direct democracy instruments, as is the case with other forms of decision-making processes, is complex, and depends on the target and goals that are set. The legitimacy of both the input and the output are difficult to measure empirically. Input legitimacy can be evaluated by opinion polls focusing on, for instance, the degree of trust in government institutions. Higher input legitimacy may strengthen political stability. Output legitimacy can be analysed by measuring the quality of policies. At the micro level output legitimacy is also an attitude to certain policies. So, opinion polls are relevant here as well.

The evaluation of referendums encompasses their effects. Both binding and consultative referendums should have an impact and their results should be accepted. It is possible to analyse whether the goal of the referendum has been achieved or whether the executive has blocked the decision made by the voters.

\section{REFERENDUMS IN SOUTHERN AND EAST AFRICA: LEGAL REQUIRE- MENTS AND IMPLEMENTATION}

All countries in Southern Africa and most in East Africa make legal provision for referendums (see table 1), with referendums constitutionally embedded. Kenya has no constitutional framework for referendums, although a constitutional referendum was held there in 2005.

Some countries make legal provision for referendums, but never hold them. In Angola, Lesotho, Swaziland, Tanzania, and Sudan this failure may be related to long periods of autocratic rule or to civil war.

Those countries which do make legal provision for referendums largely use them as a mandatory form of direct democracy, especially when it comes to constitutional amendments. Some also provide in their legal framework for referendums as optional instruments (see table). This is the case, for example, in Angola and the Sudan, where the option to hold a referendum has never been exercised. The option also exists in Namibia, which has also never held a national referendum, though it uses the instrument at sub-national level; the only country in either East or Southern Africa to do so.

South Africa held referendums at various times during the apartheid era but has not yet done so in the post-apartheid era. Rwanda, Sudan, Uganda, and Djibouti have used referendums, mostly in the form of a presidential plebiscite - a referendum held without the approval of Parliament, which is used more in francophone than in anglophone countries, though there is also provision for it in Malawi, Namibia, South Africa, Zimbabwe, and Uganda.

Apart from Uganda no country in either Southern or East Africa provides for a citizen or agenda initiative. 
Referendums in Southern and East Africa are largely restricted to constitutional issues, with countries in these regions using plebiscites or mandatory referendums to deal with certain constitutional amendments. These obligatory referendums have legal frameworks even in autocracies and dictatorships. Among the countries to make such legal provision are the Democratic Republic of Congo, Lesotho, Tanzania, Zambia, Eritrea, Rwanda, Somalia, and Sudan (IDEA 2004). Botswana and Madagascar have made extensive use of plebiscites (IDEA 2008), while Madagascar and Djibouti also allow the president to call a referendum, which, in Djibouti, may be held without the approval of Parliament.

Forty-six referendums, most of them plebiscites, have been held in the two regions. The 1960s was a boom period, with 12 referendums. The number fell to eight in the 1970s and to four in the 1980s, but increased to 12 with the wind of change in the 1990s. Between 2000 and 2008 there were nine referendums.

Every political regime uses direct democracy to give it legitimacy, but the character of referendums can be oriented towards inclusive nation-building or inclusive decision-making or towards self-legitimacy, which focuses mainly on strengthening the incumbent authority.

\section{Nation-building and inclusive decision-making}

Referendums have largely been used in the nation-building process and in political systems in transition. Apart from those in South Africa and Malawi they have mostly been symbolic instruments used at the end of a process of constitutional engineering. In South Africa the whites-only referendum held in 1992 came in the middle of such a negotiation process. In Malawi the referendum represented the symbolic end of authoritarian rule. Referendums were also a successful starting point for reconciliation and nation-building in countries such as Burundi. In other countries, the Seychelles, for instance, the debate on the Constitution continued after the referendum. In others, such as the Democratic Republic of Congo, the referendum on the new Constitution and the new political systems failed to resolve political conflicts.

\section{South Africa}

South Africa has held referendums at various points in its history, with the referendum in 1980, over whether the country should become a republic and that on 1983, on the issue of the establishment of a tricameral Parliament, exclusively for the white population. In 1992, during the negotiation process that would result in the creation of the post-apartheid state with a new constitution, South African President F W de Klerk, asked for the support of his white constituency for the reform process (Sussmann 2006; Strauss 1993; Kersting 2009, p 339). 
Voter turnout at this critical point of democratic transition was high $(85,1 \%)$, with 68,7 per cent supporting the process.

The South African Constitution of 1996 allows the president to propose a referendum without the approval of Parliament, though there have been no referendums since that date. The inclusive process of negotiating the new Constitution resulted in a document which was almost universally accepted, obviating the need for a referendum on the subject (Kersting 2007).

\section{Burundi}

The referendums in Burundi in 1991 and 1992 were constitutional referendums relating to the move towards a multiparty system. In March 1992 the most controversial topics were a five-year presidential term, renewable once, and the question of a proportional representation electoral system. Voter turnout was very high (97\%), with 90,4 per cent supporting the new Constitution. National unity was even stronger in February 2005 when a constitutional referendum focused on power-sharing between the two ethnic groups, with Hutus to have 60 per cent of positions in governmental institutions and Tutsis 40 per cent, a reconciliation policy that was strongly supported.

\section{Rwanda}

On the eve of independence in 1961 Rwanda held a referendum through which the monarchy was abolished.

\section{Djibouti}

In May 1977 the electorate voted for independence.

\section{Eritrea}

In a referendum in April 1993 the people of Eritrea voted on the question: 'Are you in favour of Eritrea becoming an independent, sovereign state?' A total of 99 per cent of registered voters cast their ballots, with 99,8 per cent of those supporting independence, support that had a symbolic value.

\section{Malawi}

In Malawi in the 1990s critics of the Banda regime emphasised human rights violations and the centralisation of power, among other concerns. President Kamuzu Banda called a referendum on the one-party system, which, according to the law, he could do without the approval of the National Assembly. Although the referendum focused on the 'introduction of a multiparty system' it also offered the option of a single-party system. For better control he favoured an open ballot with different ballot boxes for each option (Dzimbiri 1994). 
Voter turnout in the referendum, in June 1993, was 67,1 per cent, with 64,7 per cent of voters supporting a multiparty system and 35,3 per cent a single-party system. In the Central region 67,5 per cent voted in favour of keeping the one-party system, while, in the Northern region, the vote in favour of multipartyism was 89,3 per cent and in the Southern region 85,2 per cent. Here the strong influence of the old system can be recognised. Less than a year after the referendum Malawi held its first combined elections, electing both the president and members of Parliament.

\section{Seychelles}

In the Seychelles, where there is no constitutional provision for a referendum, but legislation provides for a required minimum of 60 per cent in order to effect constitutional change, a referendum was held to legitimise the country's new Constitution, which was largely written by the 15 members of the dominant party, the Seychelles People's Progressive Front (SPPF), with little input from the eight representatives of the opposition Seychelles Democratic Party (SDP).

The Seychelles has held two constitutional referendums - in November 1992 and in June 1993 - both focusing on the same topics: the presidential republic, multiparty democracy, and the official status of the leader of the opposition. In 1992, 53,7 per cent were in favour of the new Constitution, an insufficient number to meet the required minimum of 60 per cent. The political elite did not accept the outcome. Seven months later, a second referendum was held in which the Constitution was accepted with a vote of 73,9 per cent. Repetition of referendums is always problematic.

\section{The Democratic Republic of Congo (DRC)}

A constitutional referendum was held in the DRC in December 2005. Voter turnout was relatively high $(62 \%)$, with 84,3 per cent of voters supporting the main elements of a draft constitution, whose critical points were the direct election of the president and the limitation of the president's tenure to two five-year terms. Other important issues were the citizenship of all ethnic groups living in the Congo on the eve of independence in 1960 and the division of power among the president, prime minister, and Parliament.

\section{Botswana}

Referendums were held in Botswana in 1987, 1997, and 2001. In October 1997 Botswana became the only independent country in East and Southern Africa to hold a referendum that covered several different issues. A mere 16,7 per cent of the voting population turned out to vote on the question of the development of an independent electoral commission and the abolition of the Office of the Supervisor 
of Elections, which had been introduced in 1987. Of those 73,2 per cent were in favour. On the same day 70.4 per cent expressed their approval of voting rights for 'Batswana living abroad', and 58,7 per cent asked for the law to be amended to 'lower the minimum voting age from 21 to 18 '.

In November 2001 voters expressed their views on seven different issues regarding the High Court, the Judicial Service Commission, the Industrial Court, and the Chief Justice. Their views were solicited on the qualifications for appointment, retirement age, methods of nomination, and competencies. Voter turnout was a tiny 4,9 per cent and the percentage of 'Yes' votes ranged from 53,9 per cent to 76,8 per cent.

\section{Strengthening incumbent authorities}

Most referendums in East and Southern Africa are aimed less at fair decisionmaking than at strengthening incumbent authorities and are, in the main, presidential plebiscites. Populist policies are connected in an effort to strengthen the executive, with new constitutions characterised by the allocation of more powers to the president. The head of the executive controls the electorate and expects certain results. Botswana is an exception to this rule. In some countries referendums have been used to strengthen the executive and legitimate one-party systems. An example is the 1981 referendum in Burundi.

In 1992 a constitutional referendum in Djibouti focused on the introduction of a multiparty system. The voter turnout was 75,5 per cent, with 96,8 per cent voting in favour. A supplementary question relating to limiting the maximum number of parties to four was also supported by 96,8 per cent - strong support for a less fragmented political party system. However, the opposition abstained from voting in the referendum.

Ethiopia has held only one referendum, in February 1987. This focused on the Constitution and on the question of a one-party system. Voter turnout was very high - 96,3 per cent, 81 per cent of whom supported a Constitution providing for a one-party state.

Somalia held constitutional referendums at independence in 1961 and in 1979. The first was supported by 90,1 per cent of the population. In $1979,99,8$ per cent voted for a constitutional amendment establishing the framework for a single-party presidential republic.

In Rwanda in 1981 the limit on the term of office of the president was abolished and a one-party system approved. In May 2003 a constitutional referendum focused on a new political system, including such aspects as a 'presidential Republic' and a 'bicameral Parliament'. Another issue was a ban on 'inciting racial hatred'. The voter turnout was 89,9 per cent, with 93,4 per cent voting in favour. 
In Uganda, where the president can propose a referendum autonomously, the no-party system was under pressure and, in June 2000, the people were asked to choose between it and a party system (Therkildsen 2002). The voter turnout was 51,1 per cent, with 90,7 per cent voting in favour of a non-partisan system and 9,3 per cent in favour of a multiparty system. This vote reflected strong support for a dominant government and was a signal to international donors, who were pressing for democratisation. Bratton \& Lambright (2001) argue that there was an extensive 'secret boycott'.

Five years later, and still under the control of the old regime, in July 2005 the people were asked again about the introduction of a multiparty system. This time the question was framed differently. 'Do you agree to open up the political space to allow those who wish to join different organizations/parties to do so and to compete for political power?' On this occasion 92,4 per cent of the voting population voted in favour of the introduction of a multiparty system.

The swing may have been the result of campaigns organised by strong opinion leaders. In 2000 the influence of the ruling elites was strong. The need for a further referendum in 2005 indicates the interest of the population in a multiparty regime. However, it might also be the result of a campaign conducted by the government of Ugandan President, Yoweri Museveni.

In some countries referendums were used to extend executive power. Zambia has held only one constitutional referendum, in 1969. This focused on more powers for the legislature, with the question posed in the referendum relating to allowing a two-thirds majority in Parliament to amend the Constitution without resorting to a referendum. The voter turnout was 69,5 per cent, 85 per cent of whom supported the move.

The law in Madagascar provides for both mandatory referendums and presidential plebiscites. Two referendums were held in the 1970s (in 1972 and 1975) and three in the 1990s (1992, 1995 and 1998). The most recent was held in 2007. In August 1992, 72,7 per cent of the 65 per cent who turned out supported a 'presidential republic' and a 'bicameral legislature'.

Three years later, in September 1995, 63,5 per cent of the voting population voted on a constitutional amendment which would allow the president to appoint a prime minister (formerly appointed by the National Assembly), with 63,5 per cent voting in favour of the amendment.

In March 1998 a new constitutional amendment gave the president the right to dissolve Parliament. Other issues canvassed in the referendum were the introduction of a federal system and the creation of six provinces. Of the 70,3 per cent who participated only 50,9 per cent voted 'Yes', but that was sufficient for the amendment to be endorsed.

Madagascar has made a number of constitutional changes, using referendums 
extensively to endorse them, despite the fact that constitutional referendums are not mandatory - the Constitution can be amended with a 75 per cent majority of both the Senate and the National Assembly. The Council of Ministers and the President can jointly decide to refer the matter to a referendum (EISA 2008). In April 2007, 75,3 per cent of the 53,7 per cent who voted in the referendum supported constitutional amendments giving the president new emergency powers, introducing English as the third official language, and redefining the new federal system.

Zimbabwe (Rhodesia) has a long history of referendums. The referendum in 1923 nearly brought about a merger with South Africa; in November 1964, 90 per cent of 105000 whites responded to the question: 'Are you in favour of or against Southern Rhodesia obtaining independence on the basis of the Constitution of Southern Rhodesia in 1961.' The results were not recognised internationally.

In June 1969, 81 per cent of the country's white voters participated in a referendum that focused on the 'enfranchisement of all groups', the unicameral chamber, and the declaration of a republic. On the question of the voting qualification and the exclusion of most Africans from the voting process and on the question of the unicameral legislature 72,3 per cent agreed. The declaration of the republic was supported by 81,4 per cent.

During the democratic transition process in January 1979 a constitutional referendum was held. A total of 95000 white citizens registered to vote and 71,5 per cent participated. The referendum focused on the 'Presidential Republic' and, more importantly, on equal voting rights for all citizens $-45,4$ per cent of the population voted 'yes'. The referendum formed the basis of the 'internal settlement' and the following election, in April 1979. These elections were not internationally recognised and the guerilla war continued. Nevertheless, the referendum can be seen as a starting point for independence. In December 1979 negotiations began at Lancaster House in England.

Towards the end of the 1990s the opposition Movement for Democratic Change (MDC) became an important political player. The MDC, together with civil society groups, supported the idea of a constitutional referendum postulating a new electoral system and a diminution in the power of the president. The ruling Zimbabwe African National Union-Patriotic Front (Zanu-PF) responded by organising its own referendum. At the end of 1999 a Referendums Act (Act 12 of 1999) was introduced which allows the president whenever he 'considers it desirable to ascertain the view of voters on any question or issue, declare that referendum has to be held'.

In January 2000 a constitutional referendum was held. It focused on three different points -increased powers for the president, immunity from prosecution for government officials and confiscation without compensation of white-owned 
land for distribution to black farmers. This package vote encompassed policy strategy as well as institutional matters. For the first time in either of the two regions the government failed to get the result it wanted $-54,7$ per cent of those who voted opposed the proposals.

This was the first referendum in East or West Africa to fail, although, ironically, the defeat helped President Robert Mugabe to remain in power, because it failed to change the terms of the Lancaster House Constitution, which set no limit for the presidential term. Despite Mugabe's vow to respect the results, 'war veterans' and other civil society groups began to take over white farms, assaulting and forcibly evicting their occupants. Since no action was taken against them, it was clear that the Zanu-PF government did not consider the results of the referendum binding.

In April 2000 the Zanu-PF majority in Parliament voted in favour of an amendment to the Constitution allowing for the seizure of land without compensation (Makumbe 2007). Although the referendum set in motion the establishment of an increasingly authoritarian regime it also launched the MDC to prominence and, in the disputed presidential election of 2008, MDC leader Morgan Tsvangirai won a large enough percentage of the vote for there to be a run-off election.

Kenya, the second country in the two regions studied here to hold a failed referendum, has no legal provision for constitutional referendums. However, in November 2005 the people were asked to ratify a proposed new constitution, which, among other controversial proposals, would have increased presidential power by diminishing the role of the prime minister. It also included disputed issues relating to the implementation of a land commission and the extension of land reform.

Certain religious groups were opposed to sections of the proposed constitution, which established a legal framework for existing Islamic courts, resulting in protests from Christian and Hindu groups, which demanded equal rights.

Of the 6,2-million people who voted in the referendum 41,9 per cent were in favour of the proposed constitution, 58,1 per cent against. The Electoral Commission of Kenya (ECK) was praised for its independent role and the results were not disputed (Cliffe 2006).

The result was a major setback for the president, who dissolved his Cabinet, with the exception of the attorney general and the vice-president. The seven ministers who had campaigned against the draft constitution were not renominated for the new, enlarged Cabinet, which was seen as less representative than its predecessor. Parliament was prorogued until March 2006 and President Kibaki appointed a committee to report on the people's views and to identify all legal, cultural, social, and political obstacles impeding the finalisation of the 
constitutional process. The opposition Orange Democratic movement and the Law Society of Kenya criticised the structure and membership of the committee and created alternative parallel committees.

The referendum deepened the ehnicisation of Kenyan politics and led to greater political polarisation, which resulted in appalling ethnic conflict in the aftermath of the presidential election of December 2007.

\section{CONCLUSION}

In both Southern and East Africa referendums are predominantly presidential plebiscites, allowing only for a 'Yes' or 'No' vote and enabling the president to retain domination over a one-party system. There have been no citizen initiatives in the two regions and Uganda is the only country to have included the possibility of a citizen initiative in its Constitution.

In some anglophone African countries, such as Zimbabwe, South Africa, Uganda, Namibia, and Malawi, the president may propose a referendum without the approval of Parliament, enabling the president or the ruling party to use their influence in campaigning. In both regions considered in this study national referendums are usually supported by the vast majority of voters.

Like elections, referendums may be considered to have been rigged and their symbolic value may be used to legitimate a ruling party in the eyes of both opposition movements within the country and external donors.

The number of referendums held in the two regions has been high and the decisions taken are usually implemented, which is not the case in Latin America. However, as in Latin America, package votes are frequently used to win support for potentially unpopular changes hidden within the package.

There are positive aspects of direct democracy instruments when they are used as a starting point for a new political system, strengthening national identity and internal nation- and state-building processes. Externally, they show the strength and the political will of new political systems.

In this regard, referendums are the ideal instruments for postcolonial countries and those making the transition to multiparty democracy, as was the case during the third wave of democratisation. In post-conflict and post-war situations referendums may strengthen consensus. In this regard, the referendum planned in the Sudan in 2009 may be an important stepping-stone for conflict resolution. They are also useful as a democratic instrument at the end of a peacekeeping process, as they were in Rwanda in 2003 and Zimbabwe in 1979.

Referendums held at the time of independence have an important symbolic value and internal and external effects, playing an important role in creating internal political cohesion. This was the case in Burundi in 2005, although the 
referendum in the DRC in the same year did not result in similar cohesion. Referendums targeting international recognition, such as those in Eritrea and Somaliland, were also unsuccessful.

At the national level referendums are largely restricted to constitutional matters and have a strong influence on constitutional engineering with respect to the interests of citizens. In Madagascar a number of constitutional amendments, most of them oriented towards strengthening the executive, have been legitimised by referendums, although these did not result in stabilising the regime.

In the Seychelles the people were allowed to vote twice on the same issue in order for the government to gain the necessary majority, a situation similar to that in Ireland, where two referendums were held on the European Union's Nizza treaty. A similar situation pertained in Uganda, where the people voted twice on the topic of the multiparty system, with two totally different outcomes.

National referendums are used largely in relation to constitutional matters rather than policies such as, for example, structural adjustment programmes, privatisation, and so on. Furthermore, they are often package deals comprising different constitutional amendments and even - in those cases where the referendum focuses on policies - political strategies (eg, Zimbabwe 2000).

Constitutional referendums are generally complex and the complications can only be avoided through an intensive process of pre-referendum discussion and by delineating different issues.

Referendums should not become merely a form of symbolic political acclamation, they can, as they have in Kenya and Zimbabwe, strengthen the deliberative discourse between political parties and within civil society.

Political systems in Africa are predominantly characterised by a strong president and a strong executive and the dominance of one political party (a de facto one-party system), tendencies that can be weakened by a proliferation of national and local fair and free referendums.

Most countries do not provide for referendums at the local level but when they do the focus tends to be on policy issues rather than constitutional amendments and the results have a strong influence on local-government policies - the mere existence of such a referendum may lead to better and more responsive governance.

Direct-democratic procedures are an important complementary element in representative parliamentary systems with the 'latent veto function' of such instruments influencing legislators and forcing them into a kind of 'beforehand empathy' and orienting them more strongly towards civic interests (Tsebelis 2002).

Instruments of direct democracy are a kind of 'sword of Damocles' for traditional policy makers (Kersting 2007). They have an important influence on 
the pre-legislative decision-making process and the responsiveness of politicians, forcing them to make decisions and to place important issues on the agenda. They could become an important additional element of representative democracy and real participatory good governance. 

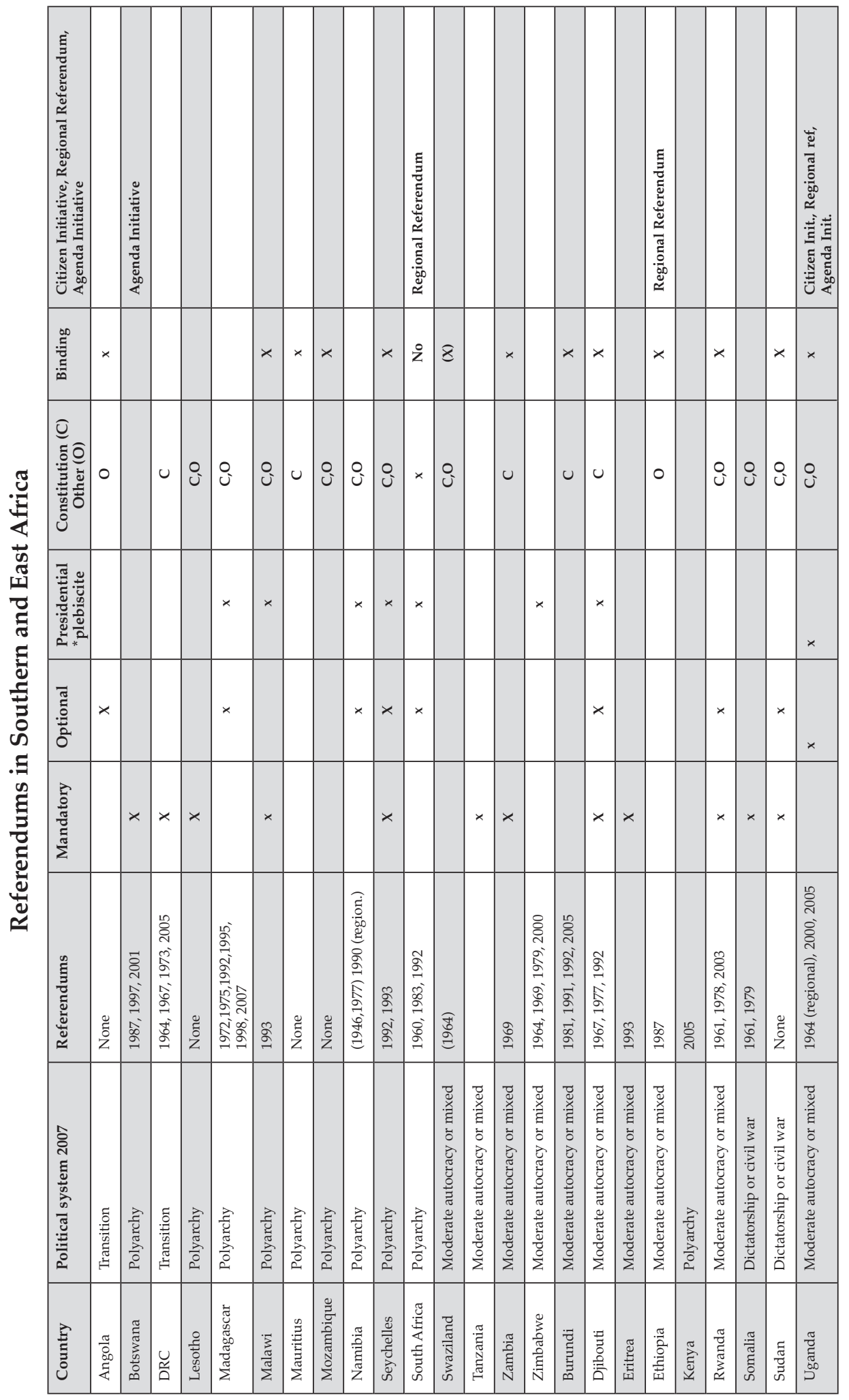

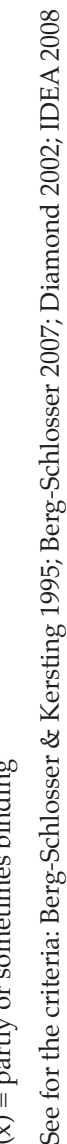




\section{- REFERENCES}

African Union. 2007. Draft Charter on Democracy, Elections and Governance. Addis Ababa: AU.

Altmann, D. 2002. 'Popular Initiatives in Uruguay: Confidence Votes on Government or Political Loyalties?' Electoral Studies 21.

Arnstein, S R. 1969. 'A Ladder of Citizen Participation'. Journal of the American Planning Association 35.

Berg-Schlosser, D \& N Kersting. 1995. 'Why worldwide democratization'. IPSA workshop, Chandigarh.

Berg-Schlosser, D. 2007. 'Determinants of Democratic Successes and Failures in Africa'. European Journal of Political Research.

Bratton, M \& N Van de Walle. 1997. Democratic Experiments in Africa. Cambridge: Cambridge University Press.

Bratton, M \& G Lambright. 2001. 'Uganda's Referendum 2000: The Silent Boycott'. Afrobarometer Working Paper. Cape Town: Afrobarometer.

Bratton, M, R Mattes \& E Gyimah-Boadi. 2005. Public Opinion, Democracy and Market Reform in Africa. Cambridge: Cambridge University Press.

Butler, D \& A Ranney (eds). 1994. Referendums Around the World. Washington, DC: American Enterprise Institute.

Chazan, N. 1979. 'African Voters at the Polls: Re-examination of the Role of Elections in African Politics'. Journal of Commonwealths and Comparative Politics 17.

Cliffe, L. 2006: Kenya's constitutional reform referendum. Review of African Political Economy 33.

Cottrell, J \& Y Ghai. 2007. 'Constitution-making and Democratization in Kenya (2000-2005)'. Democratization 14(2).

Dahl, R A. 1971. Polyarchy. Participation und Opposition. New Haven: Yale University Press.

Diamond, L. 2002. 'Thinking About Hybrid Regimes'. Journal of Democracy 13(2).

Dzimbiri, L B. 1994. 'The Malawi Referendum of June 1993'. Electoral Studies 13(3).

Good, K. 2002. 'Dealing with Despotism: The People and the Presidents'. In H Melber (ed). Zimbabwe's Presidential Elections 2002: Evidence, Lessons and Implications. Nordiska Afrikainstitutet Discussion Paper 14. Uppsala.

Hatchard, J, M Ndulo \& P Slinn. 2004. Comparative Constitutionalism and Good Governance in the Commonwealth: An Eastern and Southern African Perspective. Cambridge: Cambridge University Press.

IDEA (International Institute for Democracy and Electoral Assistance). 2004. Issues Related to Citizen Initiatives: An Electoral Processes Team Working Paper. Stockholm: IDEA. 
—. 2008. Direct Democracy Handbook. Stockholm: IDEA.

Kaufmann, B \& D Waters. 2004. Transnational Democracy in the Making. Amsterdam: IRI.

Kersting, N. 2007. 'Electoral reforms in Southern Africa: Voter Turnout, Electoral Rules and Infrastructure'. Journal of African Elections 6(1).

— 2009. 'Direct Democracy in Constitutional Processes: The South African Plebiscite 1992'. Paper presented at ECPR conference, Potsdam.

Kirschke, L. 2007. 'Semipresidentialism and the Perils of Power-sharing in Neopatrimonial States'. Comparative Political Studies 40(11).

Lindberg, S. 2004. 'Consequences of Electoral Systems in Africa: A Preliminary Inquiry'. Electoral Studies 24.

Makumbe, J. 2006. 'Electoral Politics in Zimbabwe: Authoritarianism Versus the People. Africa Development 3.

Marques, A \& Th B Smith. 1984. 'Referendums in the Third World'. Electoral Studies 3.

Nepad. 2003. Objectives, Standards and Indicators for the African Peer Review Mechanism. Johannesburg: Nepad.

Rourke, J, R P Hiskes \& C Zirakzadeh. 1992. Direct Democracy and International Politics: Deciding International Issues Through Referendums. Boulder, Co: Lynne Rienner.

Schiller, Th. 2002. Direkte Demokratie. Eine Einführung. Frankfurt: Campus.

___. \& V Mittendorf. 2003. Direkte Demokratie. Forschung und Perspektiven. Wiesbaden: Westdeutscher Verlag.

Schmitter, Ph \& A Trechsel. 2004. The Future Of Democracy in Europe: Trends, Analysis and Reforms. A green Paper for the Council of Europe. Strassburg.

Strauss, A. 1993. 'The 1992 Referendum in South Africa. Journal of Modern Africa Studies 31(2).

Suksi, M. 1993. Bringing In the People: A Comparison of Constitutional Forms and Practices of the Referendum. Turku: Abo Academy.

Sussman, G. 2006. 'The Referendum as an Electoral Device in National Party Politics, 1917-60. Politikon 33(3).

Therkildsen, O. 2002. 'Uganda's Referendum 2000: The Silent Boycott: A comment'. African Affairs 101(403).

Tsebelis, G. 2002. Veto Players: How Political Institutions Work. Princeton: Princeton University Press.

Whitaker, B E \& J Giersch. 2009. 'Voting on a Constitution: Implications for Democracy in Kenya'. Journal of Contemporary African Studies 27(1). 